\title{
Identification of runoff formation with two dyes in a mid-latitude mountain headwater
}

\author{
Lukáš Vlček $^{1}$, Kristýna Falátková ${ }^{1}$, and Philipp Schneider ${ }^{2}$ \\ ${ }^{1}$ Department of Physical Geography and Geoecology, Charles University, Prague, Czech Republic \\ ${ }^{2}$ Department of Geography, University of Zurich, Zurich, Switzerland \\ Correspondence to: Philipp Schneider (philipp.schneider@geo.uzh.ch)
}

Received: 11 February 2017 - Discussion started: 17 February 2017

Revised: 8 May 2017 - Accepted: 14 May 2017 - Published: 23 June 2017

\begin{abstract}
Subsurface flow in peat bog areas and its role in the hydrologic cycle has garnered increased attention as water scarcity and floods have increased due to a changing climate. In order to further probe the mechanisms in peat bog areas and contextualize them at the catchment scale, this experimental study identifies runoff formation at two opposite hillslopes in a peaty mountain headwater; a slope with organic peat soils and a shallow phreatic zone $(0.5 \mathrm{~m}$ below surface), and a slope with mineral Podzol soils and no detectable groundwater ( $>2 \mathrm{~m}$ below surface). Similarities and differences in infiltration, percolation and preferential flow paths between both hillslopes could be identified by sprinkling experiments with Brilliant Blue and Fluorescein sodium. To our knowledge, this is the first time these two dyes have been compared in their ability to stain preferential flow paths in soils. Dye-stained soil profiles within and downstream of the sprinkling areas were excavated parallel (lateral profiles) and perpendicular (frontal profiles) to the slopes' gradients. That way preferential flow patterns in the soil could be clearly identified. The results show that biomat flow, shallow subsurface flow in the organic topsoil layer, occurred at both hillslopes; however, at the peat bog hillslope it was significantly more prominent. The dye solutions infiltrated into the soil and continued either as lateral subsurface pipe flow in the case of the peat bog, or percolated vertically towards the bedrock in the case of the Podzol. This study provides evidence that subsurface pipe flow, lateral preferential flow along decomposed tree roots or logs in the unsaturated zone, is a major runoff formation process at the peat bog hillslope and in the adjacent riparian zone.
\end{abstract}

\section{Introduction}

Hydrologic extremes in central Europe during recent decades have stimulated debates over sustainable solutions and suitable, cost-efficient strategies to prevent or mitigate the impacts of droughts and floods. Floods on the Vltava and Elbe River are documented back to Middle Ages (Brázdil et al., 2015; Faist, 1967) as having had devastating impacts on infrastructure and the economy. However, a system of dams and reservoirs, which was built in the Vltava catchment - the main drainage of the Šumava Mts. in the 1960s - failed to prevent major floods in 2002 (Hladný et al., 2005; Hladný, 2009 ) or 2013. These floods were mainly caused by heavy rainfall in summer or by rain on snow events. As the Šumava Mts. and the Vltava catchment are promising water resources, research efforts have focused on this area.

Peat bogs (PB) are prominent in the Šumava Mts., which affects water quality and storm discharge (Ferda et al., 1971; Janský and Kocum, 2008; Vlček et al., 2016). Streamflow in peaty catchments is characterized by its quick rise and fall, and huge volatility: very low baseflows during dry periods and spiky storm hydrographs caused by heavy rainfall events (Evans et al., 1999; Holden et al., 2001; Holden, 2005). However, most of these studies have focused on pure peat areas only. In the Šumava Mts., peat bog covers approx. $35 \%$ of the catchments in this region, but the larger proportion of these catchments is covered by mineral soils. Although peat bogs are not dominating the catchment area, their hydrology determines the runoff processes (Vlček et al., 2012). In order to establish the relative roles of peat bog and Podzol in this type of catchment, this study focused on a comparison of runoff formation on contrasting soil types - namely a mountain Histosol/peat bog and a Podzol (PZ) on opposite hillslopes of the 
headwater - representing organic and mineral soil properties, respectively.

Sprinkling experiments with sorptive dye tracers have been successfully applied at the plot and hillslope scale in many different environments (Bachmair et al., 2009, 2012; Hümann et al., 2011; Flury and Flühler, 1995; Schneider et al., 2014; Weiler and Flühler, 2004; Weiler, 2011; Wienhöfer et al., 2009) and are an established method to identify interactions between infiltration, preferential flow, matrix flow and percolation. The sorptive dye Brilliant Blue (BB) FCF, is probably the most widely used dye tracer in such sprinkling experiments (Flury and Flühler, 1995). Successful experiments using BB at mineral soil test sites identified significant processes during the formation of storm runoff such as infiltration and initiation of vertical preferential flow in macropores (Weiler and Flühler, 2004), infiltration and vertical preferential flow dependence on soil structures, soil type and land use (Bachmair et al., 2009; Weiler and Flühler, 2004), lateral preferential flow in a soil pipe network (Anderson et al., 2009; Wienhöfer et al., 2009) and lateral preferential flow in organic topsoil layer/biomat flow (Schneider et al., 2014).

Almost all headwaters of the Šumava Mts., including the Rokytka catchment, have been affected by bark beetle calamity and by storm activity; e.g., the storm Kyrill in 2007 uprooted many trees. These disturbances have been shown to have a long-term impact on runoff formation in headwater systems (Langhammer et al., 2015). However, it is unclear how these disturbances modify specific runoff formation processes like infiltration, lateral drainage (soil piping) or percolation in riparian soils.

However, runoff formation at hillslopes, particularly subsurface stormflow (SSF), is highly variable and complex (Bachmair and Weiler, 2012). To evaluate both vertical and lateral preferential subsurface flow in the Rokytka headwater, we conducted two separate sprinkling experiments on each soil type with two different dye tracers with different properties. The experiments in this study were conducted in the vicinity of a headwater stream where the riparian zone connects to the two hillslopes. The test site was selected for several reasons:

1. Runoff formation control - the riparian zone represents a potential buffer in hydrologic connectivity between hillslopes and a stream (Von Freyberg et al., 2014; Seibert et al., 2009).

2. Representativeness - the two slopes are covered by prevailing soil types in the Šumava Mts. (Podzol, Histosol).

3. Tracer detection in a stream - hydrologic connectivity of a hillslope and a stream can be detected and potentially quantitatively described by conservative tracers such as Fluorescein sodium (FLC, also Uranine). Therefore, proximity of a stream is favorable in terms of timesaving and lesser dilution of a tracer.
Table 1. Selected dye-sprinkling experiments sorted by land use and scale of dye application.

\begin{tabular}{|c|c|c|c|}
\hline & Land use & Plot studies & Hillslope studies \\
\hline \multirow{2}{*}{ 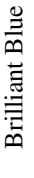 } & $\begin{array}{l}\text { Forest } \\
\text { studies }\end{array}$ & $\begin{array}{l}\text { Bachmair et al. (2009); } \\
\text { Wienhöfer et al. (2009) }\end{array}$ & $\begin{array}{l}\text { Anderson et al. (2009); } \\
\text { Wienhöfer et al. (2009) }\end{array}$ \\
\hline & $\begin{array}{l}\text { Grassland } \\
\text { studies }\end{array}$ & $\begin{array}{l}\text { Weiler and Flühler (2004); } \\
\text { Bachmair et al. (2009); } \\
\text { Schneider et al. (2014) }\end{array}$ & - \\
\hline \multirow{2}{*}{ 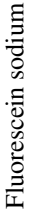 } & $\begin{array}{l}\text { Forest } \\
\text { studies }\end{array}$ & $\begin{array}{l}\text { Gerke et al. (2008, } \\
2013,2015)\end{array}$ & $\begin{array}{l}\text { Wienhöfer et al. (2009); } \\
\text { Weiler and Naef (2003) }\end{array}$ \\
\hline & $\begin{array}{l}\text { Grassland } \\
\text { studies }\end{array}$ & - & $\begin{array}{l}\text { Weiler and Naef (2003); } \\
\text { Schneider (2007); } \\
\text { Schneider et al. (2014) }\end{array}$ \\
\hline
\end{tabular}

The sorptive tracer BB was used mainly to detect vertical flow, and the conservative tracer FLC was used to detect vertical and lateral flow at two opposite hillslopes with different soil types (peat bog and Podzol). Furthermore, based on other studies in dark-colored organic soils (Markus Weiler, personal communication, 2014), we considered that BB-stained soil patterns may be difficult or impossible to identify in the peat bog. Thus, we adapted a successful dye tracer soil staining experiment applied in organic forest soils using FLC (Gerke et al., 2008). FLC can be used to identify preferential flow patterns by staining soil particles (Gerke et al., 2015), and as a tracer detecting lateral subsurface flow and thus hydrologic connectivity and potentially tracer breakthrough into a stream or a spring equipped with automated water samplers or field fluorometers. Thus, FLC provides two functions in parallel: vertical and lateral soil staining of preferential flow structures and lateral connectivity between the sprinkling plots (lower, convex part of the hillslopes) and the stream or springs. In theory, such a combined FLC experiment could link plot and hillslope experiments and thus provide additional insights into the mechanical understanding of the entire hillslope-riparian zone-stream system and thus providing an estimate where (flow paths), when (timing, delay) and possibly how much hillslopes with different soils contribute to discharge in headwaters. Examples of applications of the dyes BB and FLC are shown in Table 1. To summarize, the objectives of this study are to identify runoff formation at both prevailing soil types (Histosol/Peat, entic Podzol) with emphasis on the following aspects:

- Identify infiltration and vertical preferential flow in the unsaturated zone in soil profiles - as well as possible infiltration barriers causing lateral flow on the plot scale.

- Identify soil horizons and/or structures, where vertical flow translates into lateral preferential flow, e.g., whether lateral preferential flow occurs in partially saturated parts in the unsaturated zone, or expanding fully saturated horizons promote transmissivity feedback. 
- Identify vertical percolation in the saturated zone; determine whether infiltrated water percolates deep into the bedrock and thus a "secondary" (strongly delayed) drainage system is recharged during storms - plot scale.

- Identify lateral preferential flow paths and possibly estimate lateral flow velocities in the soil - hillslope scale.

\section{Materials and methods}

\subsection{Study site}

The $3.8 \mathrm{~km}^{2}$ Rokytka headwater is a tributary to the Otava River, located in the central part of Šumava Mts. The secondorder stream drains $0.6 \mathrm{~km}^{2}$ of the Rokytka headwater covering an altitude range between 1100 and $1260 \mathrm{~m}$ a.s.l. The test site can be divided into two parts - two opposite hillslopes with different soils and vegetation cover (Fig. 1). The mineral soil hillslope consists of a Podzol (PZ hillslope) and is covered by beech stands at the upper hillslope zone PZ1 and dead spruce stands with healthy seedlings at the lower hillslope zone PZ2. The soil profiles are similar throughout the slope without a clear gradient towards the stream. The soil type has been identified as an entic Podzol with a shallow organic top layer $(<5 \mathrm{~cm})$ and similar soil texture (Table 2) to a depth of $1 \mathrm{~m}$. Some small parts of the mineral soil hillslope PZ are covered by haplic Podzol, but these areas are hardly identifiable without excavation. Neither there was a sharp transition between the mineral soil and the bedrock (wellweathered gneiss or granite) perceptible with ERT measurements, nor could a persistent groundwater level be detected. The organic soil hillslope is covered by a well-developed mountain peat bog (PB hillslope). The entire PB area consists of a mixture of various stages of decomposed peat; however, acrotelm and lower catotelm can be distinguished at depths ranging from 8 to $25 \mathrm{~cm}$. Vegetation and soil depth vary according to the position along the hillslope forming a catena. The upper organic soil hillslope zone is covered mostly by cotton grass (Eriophorum sp. L.) or moss (Sphagnum sp. L.; PB1 in Fig. 1). This zone has the highest water table fluctuations and the depth of the PB is $4-5 \mathrm{~m}$. The vegetation cover at the lower hillslope zone (PB2 in Fig. 1) consists of pine (Pinus mungo), blueberry (Vaccinium myrtillus) and moss. The riparian zone (PB3 in Fig. 1) forms the bottom of the valley, which is covered by a waterlogged spruce forest with blueberry and moss. The depth of the PB varies from $1 \mathrm{~m}$ in the riparian zone $\mathrm{PB} 3$ up to $5 \mathrm{~m}$ in the upper hillslope zone PB1 (Fig. 1).

Despite the differences between an organic and a mineral soil at the two hillslopes, the basic soil properties - which have a strong impact on infiltration and subsurface stormflow - are rather similar (Table 1). Vertical hydraulic conductivity $\left(\mathrm{HC}_{\mathrm{V}}\right)$ was measured on-site with a single-ring infiltrometer (Flow-Group Comp.). Low values of $\mathrm{HC}_{\mathrm{v}}$ are contrasted by the high effective porosity. This contrast is caused by relatively few macropores compared to other soils and a high percentage of small pores, which are mostly not active during the infiltration process. A low $\mathrm{HC}_{\mathrm{v}}$ in the topsoil is supposed to generate surface flow - likely saturation overland flow (SOF) and possibly Hortonian overland flow (HOF) to a minor extent - or near-surface biomat flow (BMF; Sidle et al., 2007) during high intensity storms. However, at the mineral soil hillslope PZ no surface flow has been observed even during large storms with daily precipitation sums of up to $80 \mathrm{~mm}$. At the organic soil hillslope PB, surface flow can be observed at times when the peat bog is saturated.

In general, the dominant runoff formation process in most forested mountain headwater catchments can be described as SSF (Weiler et al., 2006). However, site-specific soil types and their properties, such as those at our test site, peat bog (PB3) and entic Podzol (PZ2), may result in a characteristic and possibly unique combination of runoff formation processes. Based on our field surveys and soil mapping using the Hydrology of Soil Types classification (HOST, Boorman et al., 1995), the Podzol at the mineral soil hillslope PZ2 was classified as hydrological soil class 4 , meaning it is a "mineral soil, aquifer $>2 \mathrm{~m}$ depths, no impermeable layer, consolidated substrate" and conceptual runoff formation model A. The latter model implies "The dominant water movement is downwards through the vadose zone to an aquifer at least two meters below the surface. Lateral movement is largely confined to the saturated zone, with the hydrological response being controlled by the flow mechanisms of the substrate. Where the rock is more coherent but deeply weathered or fissured, the dominant flow is via the fissures as the bulk of the rock is only slightly porous at best. Aquifers or groundwater are more rarely found in this group" (Boorman et al., 1995). The peat bog at the organic soil hillslope PB3 was classified as hydrological soil class 12 meaning organic soils, no significant aquifer, raw peaty topsoil, substrate raw peat, upper soil layers remain saturated for much of the year and conceptual model $\mathrm{K}$, which implies "Where there is deep peat, the flow is dominated by surface and immediate subsurface flow, with the underlying substrate having little influence on the hydrological response" (Boorman et al., 1995).

\subsection{Hydrologic conditions of the Rokytka headwater}

In these catchments, the retention ability depends mainly on the shallow depth of the phreatic zone in the peat bog, whereas the deep phreatic zone in the Podzol plays a minor role (Vlček et al., 2012). Peat bog areas are hypothesized to control storm runoff formation in these headwaters. Peat bogs can significantly contribute to stormflow when the peat is fully saturated, i.e., storm events exceeding a threshold of 10-15 mm (Vlček et al., 2016). According to a geochemical study based on 2 years of monthly stream water sampling (Kocum et al., 2016), peat bogs contribute only $10 \%$ to baseflow at the outlet of the entire Rokytka catchment $\left(3.8 \mathrm{~km}^{2}\right)$. 

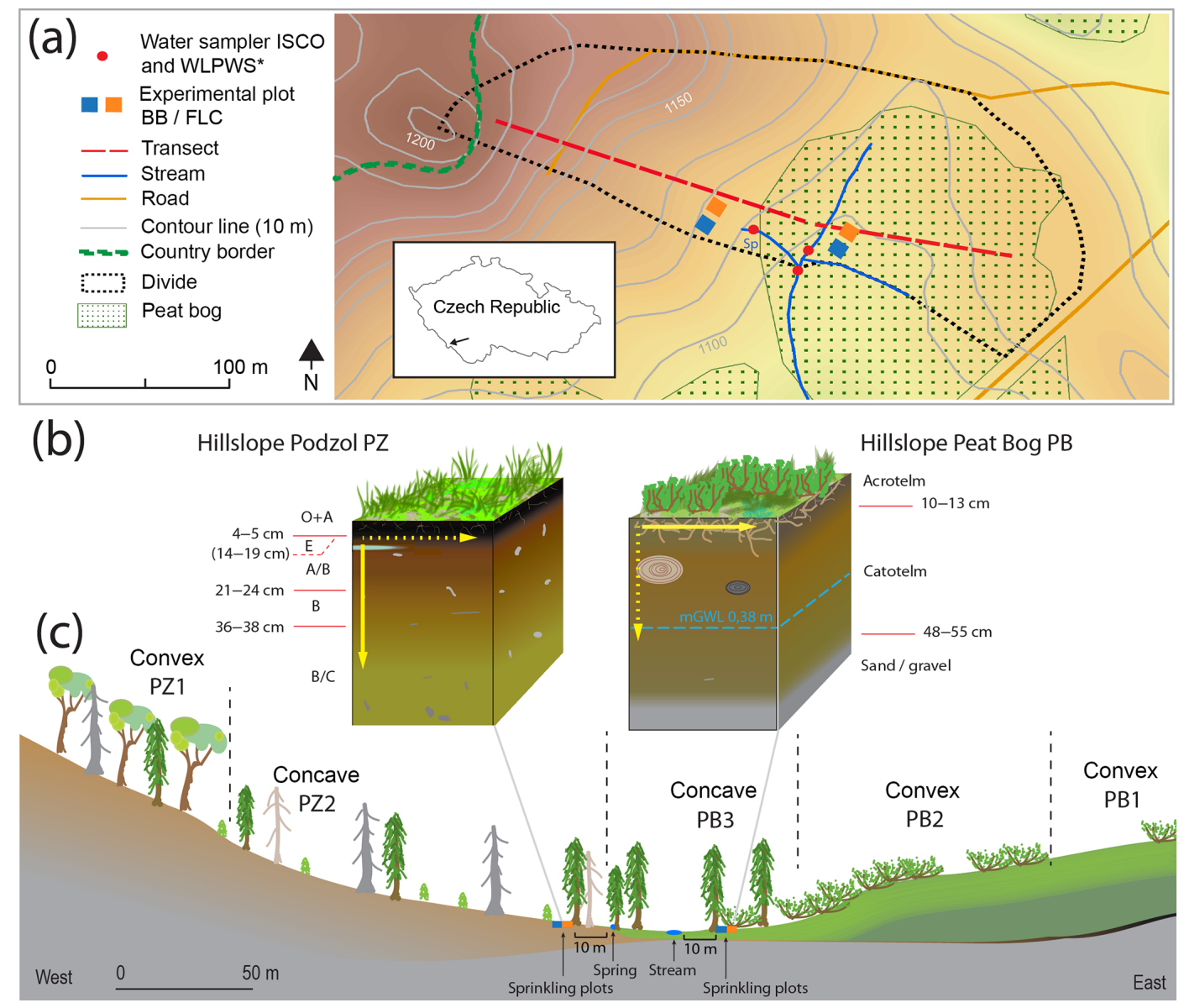

Figure 1. (a) Overview of the Rokytka headwater test site $\left(0.6 \mathrm{~km}^{2}\right)$ in the Šumava Mts. in southwestern (SW) Czech Republic; $\mathrm{Sp}=\mathrm{spring}$; * Water-level proportional water sampler (Schneider et al., 2013). (b) The yellow arrows at the experimental Podzol plot PZ2 and the peat bog plot PB3 represent simplified conceptual models of assumed runoff formation during stormflow according to the Hydrology of Soil Types classification (HOST; Boorman et al., 1995): The soil type entic Podzol at plot PZ2 matches HOST soil class 4 with conceptual model A; the soil type peat bog at plot PB3 matches HOST soil class 12 with conceptual model K (Fig. 8). (c) Cross section of the Rokytka headwater and its two opposite hillslopes. The mineral soil hillslope Podzol (PZ) consists of entic or at least haplic Podzol and is covered by beech and spruce stands. The organic soil hillslope (PB1-PB3) represents a typical peat bog (PB) of the Šumava Mts. The upper hillslope zone PB1 (cotton grass), the lower hillslope zone PB2 (pine) and the riparian zone PB3 (waterlogged spruce forest) represent zones of the PB catena with different vegetation cover, groundwater and peat soil depths.

However, some zones of a peat bog area, such as springs or soil pipe systems connected to the stream, exhibit high fluctuations in discharge (Holden and Burt, 2002). This could explain the observed spiky storm hydrographs at the entire Rokytka catchment outlet $\left(3.8 \mathrm{~km}^{2}\right)$ and at the Rokytka headwater test site $\left(0.6 \mathrm{~km}^{2}\right)$. Pronounced discharge fluctuations from Peat areas could be caused by surface flow (field observation at the Rokytka peat bog), near-surface (Holden et al., 2001; Holden, 2005) or subsurface stormflow in soil pipes (Rizzuti et al., 2004; Holden, 2005; Gerke et al., 2015). Results of Holden and Burt (2003) at a blanket Peat site showed that near-surface flow (Biomat flow, BMF) up to the depth of $10 \mathrm{~cm}$ can contribute more than $90 \%$ to the plot's outflow. BMF is defined as lateral stormflow in the organic litter layer with high porosity and high hydraulic conductivity in the topsoil (Gerke et al., 2015).

Storm hydrographs at the Rokytka headwater are highly volatile and are characterized by quick and steep rising and falling limbs. The hydrologic response to rainfall events is fast and the recession to antecedent baseflow occurs rather quickly (Fig. 2). The average annual mean flow Mq at the Rokytka headwater outlet is about $0.098 \mathrm{~mm} \mathrm{~h}^{-1}$ $\left(860 \mathrm{~mm} \mathrm{a}^{-1}\right)$; yet at 330 days of the year $(>90 \%)$ the discharge is lower. Compared to the average, the hydrologic year 2015 (1 November-31 October) was a rather dry year with total annual precipitation of $840 \mathrm{~mm}$ (long-term average $1220 \mathrm{~mm}$ ) and total runoff of $580 \mathrm{~mm}$ or $0.07 \mathrm{~mm} \mathrm{~h}^{-1}$ (long-term average $860 \mathrm{~mm}$ ). Mean annual maximum flow $\mathrm{MHq}$ is $2.24 \mathrm{~mm} \mathrm{~h}^{-1}$ and mean annual minimum flow $\mathrm{MNq}$ 

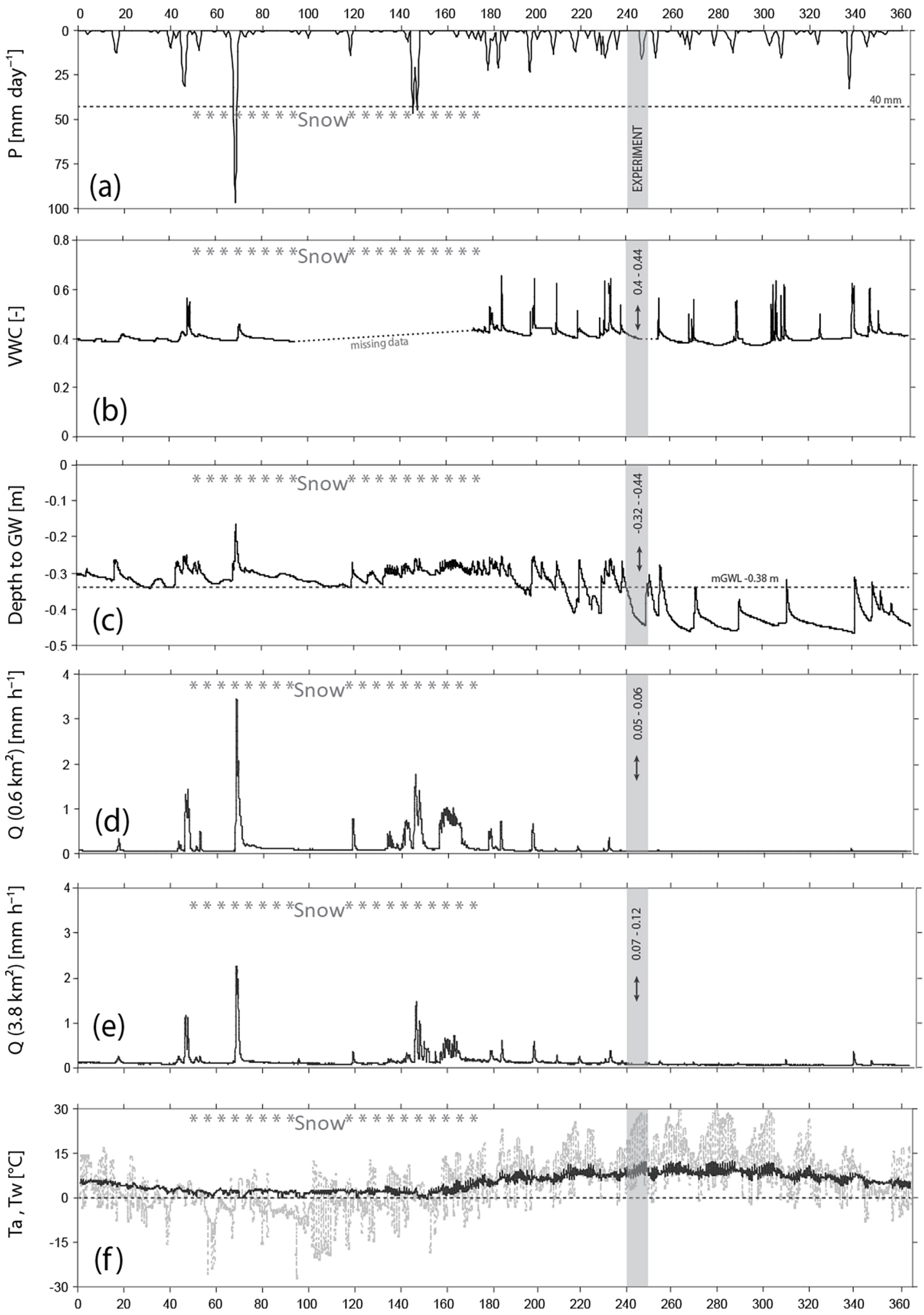

Figure 2. Hydro-meteorological data of the water year 2015 (1 November 2014-31 October 2015). (a) $P$ : precipitation [mm d $\mathrm{m}^{-1}$ ]. (b) VWC: volumetric water content at hillslope PZ in $0.2 \mathrm{~m}$ depth [-]. (c) Depth to groundwater level at slope PB3. (d) $Q\left(0.6 \mathrm{~km}^{2}\right)$ : discharge [mm h${ }^{-1}$ ] of Rokytka headwater. (e) $Q\left(3.8 \mathrm{~km}^{2}\right)$ : discharge $\left[\mathrm{mm} \mathrm{h}^{-1}\right]$ of Rokytka catchment $\left(3.8 \mathrm{~km}^{2}\right)$. (f) $T_{\mathrm{a}}$ : air temperature $\left[{ }^{\circ} \mathrm{C}\right]$ (dashed gray line), $T_{\mathrm{w}}$ : stream water temperature $\left[{ }^{\circ} \mathrm{C}\right]$ (solid black line). The gray bars mark a 10-day period starting with dye tracer sprinkling in the evening of 29 June (day 240 of the water year) and 8 July (day 249 of the water year). 
Table 2. Soil characteristics at the two experimental plots PZ and PB in the Rokytka headwater. PZ is Podzol (mineral soil), PB is peat bog (organic soil); RH is coverage of a selected soil type at the Rokytka Headwater; OR is coverage of a selected soil type at the Otava River Headwater; * peat in general is Histosol according to IUSS Working Group WRB (2006); ** depth at hillslope PB3; SL is sandy loam; L is loam.

\begin{tabular}{|c|c|c|c|c|c|c|c|c|c|}
\hline Slope & Soil type & $\begin{array}{r}\text { Soil area [\%] } \\
\text { RH/OR }\end{array}$ & $\begin{array}{r}\text { Soil depth }[\mathrm{m}] \\
\mathrm{RH} / \mathrm{OR}\end{array}$ & $\begin{array}{l}\text { Depth to }[\mathrm{m}] \\
\text { groundwater }\end{array}$ & $\begin{array}{r}\text { Slope } \\
{[\%]}\end{array}$ & $\begin{array}{l}\text { Soil } \\
\text { layer }\end{array}$ & $\begin{array}{l}\text { Eff. [\%] } \\
\text { porosity }\end{array}$ & $\begin{array}{r}\left.\text { Hydrol. [mm h}{ }^{-1}\right] \\
\text { cond. }\end{array}$ & $\begin{array}{l}\text { Soil } \\
\text { texture }\end{array}$ \\
\hline \multirow[t]{2}{*}{$\mathrm{PZ}$} & $\begin{array}{l}\text { entic } \\
\text { Podzol }\end{array}$ & $51 / 45$ & $0.7 / 0.4-0.7$ & $>2.0$ & $4-6$ & $\mathrm{~A} / \mathrm{B}$ & 80.0 & 0.50 & SL-L \\
\hline & & & & & & B & 53.5 & 0.38 & SL \\
\hline PB & Histosol* & $44 / 20$ & $2.1 / 1.2^{* *}$ & 0.35 & $3-5$ & $\mathrm{~T}$ & 89.2 & 0.30 & - \\
\hline
\end{tabular}
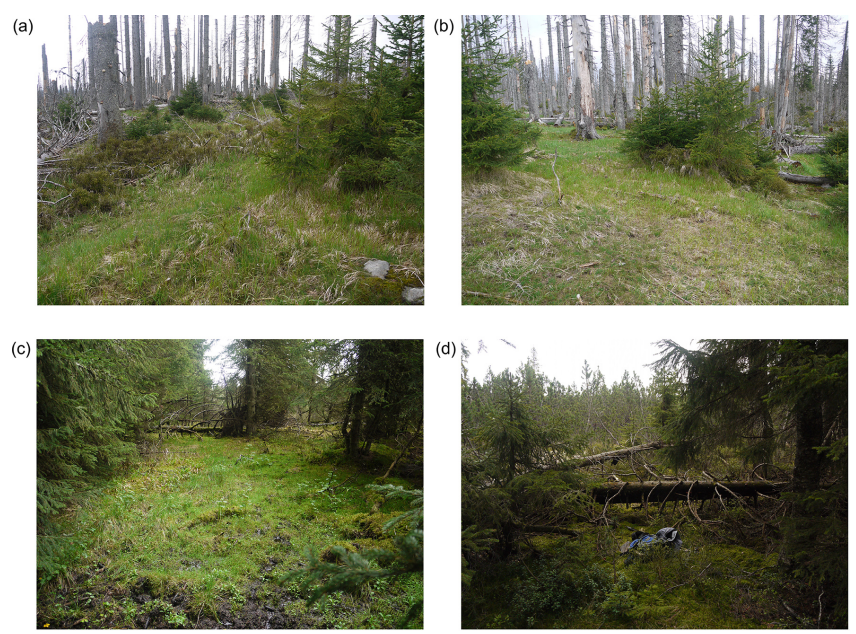

Figure 3. Pictures of the application plots of the dye-sprinkling experiments at the Rokytka headwater, Šumava Mts., Czech Republic. (a, b) Sprinkling plots at the mineral soil hillslope Podzol (PZ2). (a) Brilliant Blue plot (BB); (b) Fluorescein sodium plot (FLC). (c, d) Sprinkling plots at the organic soil hillslope peat bog (PB3). (c) Brilliant Blue plot (BB); (d) Fluorescein sodium plot (FLC).

is $0.04 \mathrm{~mm} \mathrm{~h}^{-1}$. The peak discharge $\mathrm{Hq}_{\mathrm{p}}$ in 2015 reached $3.5 \mathrm{~mm} \mathrm{~h}^{-1}$ (Fig. 2); thus, the ratio $\mathrm{Hq}: \mathrm{Mq} \approx 50$ is relatively high. From June to October 2015 daily precipitation rarely exceeded $10 \mathrm{~mm} \mathrm{~d}^{-1}$ and thus storm-flow events were unfrequent and small. Yet, the Rokytka creek did not fall dry due to two persistent springs at the mineral soil hillslope PZ. In contrast, springs at the organic soil hillslope PB are susceptible to desiccation.

\subsection{Dye tracer experiments}

The dye tracer experiments were carried out at both hillslopes (mineral soil slope PZ2 and organic soil slope PB3) of the Rokytka headwater during baseflow conditions in late June 2015. At each hillslope two $1.5 \mathrm{~m} \times 1.5 \mathrm{~m}$ plots were sprinkled with both dyes (Brilliant Blue, CAS no. 3844-459 , concentration $5 \mathrm{~g} \mathrm{~L}^{-1}$; Fluorescein sodium, CAS no. 51847-8, concentration $2 \mathrm{~g} \mathrm{~L}^{-1}$ ). All sprinkling plots are located at the transition between the concave, lower part of the hills- lope and riparian zone in the vicinity of the stream (distance to stream $\approx 10 \mathrm{~m}$; Fig. 3 ).

First, all plots were pre-sprinkled with $45 \mathrm{~L}(\approx 20 \mathrm{~mm})$ of local stream water to raise soil moisture and connect the pathways for water percolation, and then the plots were sprinkled with $45 \mathrm{~L}(\approx 20 \mathrm{~mm}$ ) of dye solution. The overall sprinkling time at each plot was $\sim 2 \mathrm{~h}$ in order to simulate a rainfall intensity of $20 \mathrm{~mm} \mathrm{~h}^{-1}$. These amounts and intensities represent a heavy rainfall storm in the Šumava Mts. Due to previous rainfall events, the soil moisture ranged between 0.40 and $0.45 \mathrm{VWC} ; 40 \mathrm{~mm}$ rainfall usually causes significant stormflow and also represents frequently occurring amounts of daily precipitation in central Europe low mountain ranges (Hümann et al., 2011). Storms of this magnitude occur 2-3 times in an average year in the Šumava Mts. (Fig. 2). The groundwater level in the peat bog was initially about $0.35 \mathrm{~m}$ below the terrain surface (Fig. 2), which represents average peat bogs summer groundwater levels at the near-riparian organic soil hillslope.

$\mathrm{pH}$ is an important parameter when using FLC as a soil staining dye for preferential flow identification (Gerke et al., 2008, 2013). The soils in the Šumava Mts. are characterized by low $\mathrm{pH}$ values ranging from extremely acidic $\mathrm{pH} 3.8$ for peat bogs to moderately acidic pH 6.0 for Cambisols. In the Rokytka headwater soil $\mathrm{pH}$ is very strongly acidic $\mathrm{pH} 4.8$ at the peat bog plot PB3 and strongly acidic pH 5.4 at the mineral soil plot PZ2. Therefore, a $\mathrm{NaOH}$ solution was added during the initial pre-sprinkling with dye-free water $(\mathrm{pH} \mathrm{12})$ to raise and buffer the soil $\mathrm{pH}$ to reduce fluorescence suppression of FLC caused by a very strongly acidic environment.

The experiment continued with excavation of the FLCsprinkling plots. The excavation of soil profiles and the photography of FLC-stained soil structures were performed under short-time ultraviolet (UV) illumination $(410 \mathrm{~nm})$ at night, approx. $4 \mathrm{~h}$ after sprinkling, as FLC is strongly light sensitive (Käss, 1998).

In the following we describe the soil profile excavation and photo documentation procedure performed after the sprinkling step by step. First, we visually surveyed the terrain surface and all micro-depressions downslope of the sprinkling plots along the primary topographic gradient (thalweg) towards the stream to identify potential preferential flow pat- 

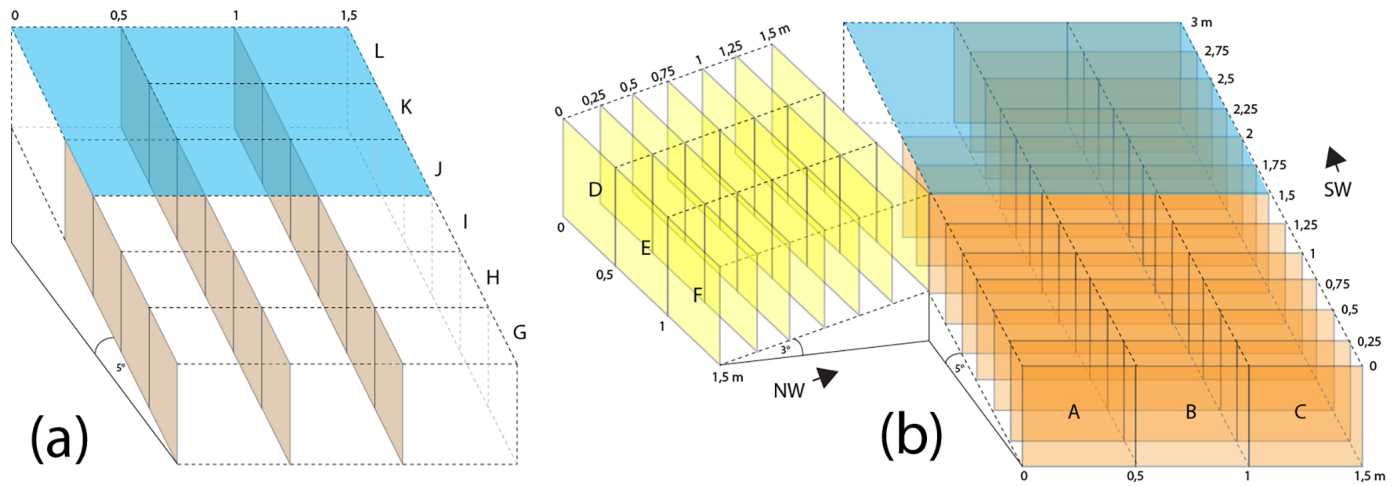

Figure 4. Sketch of the dye tracer experiment excavation directed along the flow lines. (a) Scheme of excavation and photography of lateral soil profiles (gray) parallel to the lateral-horizontal preferential flow paths (rows G-L). Blue areas show the dye-sprinkling plots, where "platform" images where taken of horizontal layers of the soil (these layers have the same orientation as the soil layer boundaries). (b) Scheme of excavation and photography of frontal soil profiles (orange and yellow sections) up the slope ("columns" A-F). The yellow inclined part (columns D-F) was only excavated and photographed at plot PB3 to capture the dominant lateral-horizontal preferential flow paths.

terns near or at the surface. In case of visible dye patterns at the surface, exploratory frontal soil pits, perpendicular to the horizontal/lateral flow, would start at the stained surfaces nearest to the stream. Second, the systematic frontal profile excavation started $1.5 \mathrm{~m}$ downslope from the sprinkling plots outside of the sprinkling area along the projected flow direction along the thalweg (Fig. 4). Third, the preplanned systematic excavation was extended along possible secondary gradients using additional exploratory frontal profiles at local terrain depressions. These were excavated up to $10 \mathrm{~m}$ down the slope to find potential secondary flow directions and to identify the maximum distance of dyestained flow structures. Fourth, lateral profiles, oriented parallel to the flow, were excavated in a systematic way at all places where the dyes were detected outside of the sprinkling area. Fifth, the sprinkling area was excavated in a predefined systematic way (Fig. 4). The pictures of soil profiles were taken from two sides in frontal and lateral orientation. Frontal images were taken towards the slope (perpendicular to the direction of horizontal-lateral flow), whereas lateral images were taken along the slope (parallel to the direction of horizontal-lateral flow). The size of each image (photograph) was $50 \mathrm{~cm} \times 50 \mathrm{~cm}$.; lateral pictures (Fig. $4 \mathrm{a}$ ) were taken in soil pit profile lines every $0.5 \mathrm{~m}(\mathrm{G}-\mathrm{L})$, frontal pictures in soil pit profile rows at every $0.25 \mathrm{~m}$ (Fig. 4b). A similar system of excavation was used by Schneider et al. (2014) and Gerke et al. (2015).

Pictures of the soil profiles were taken during the excavation with a digital Micro Four Third camera with a crop factor of 2.0 (Panasonic Lumix DMC-G1 with a 12 MP MOS sensor, $13 \mathrm{~mm} \times 17.3 \mathrm{~mm}$ sensor area and a $14-45 \mathrm{~mm}$ zoom lens, mostly at a focal length of $14 \mathrm{~mm}$, equivalent to $28 \mathrm{~mm}$ in full format $/ 35 \mathrm{~mm}$ film) under daylight conditions beneath a shading tarp to avoid direct sunlight and shadow effects in case of the BB plots. White balance, white point and black point reference were calibrated using a Datacolor Spider Cube, which was placed in every image. Pictures at the FLC plot were taken at night with the same camera. Each FLC soil profile was illuminated separately with two light sources:

1. a $500 \mathrm{~W}$ Halogen lamp (approx. light temperature $5500 \mathrm{~K}$ in the visible spectra with maximum $550 \mathrm{~nm}$ ) to document the natural soil profile color with its horizons;

2. a 27 W UV LED lamp $(9 \times 3$ W UV LEDs, Highlite International BV Comp.) producing UV light $410 \mathrm{~nm}$ with a $120^{\circ}$ beam angle to visualize fluorescent FLC-stained soil structures similar to Gerke et al. (2013).

The dye-stained flow patterns for both dyes BB and FLC at all soil profiles were analyzed according to a method and with an analytical tool described by Weiler and Flühler (2004). This method was originally developed for analyzing BB. Therefore, the color space of the photographs is converted from the red-green-blue (RGB) color space taken by the camera sensor into the hue-saturation-value (HSV) color space and then classified and spatially analyzed with an algorithm written in IDL code (Weiler and Naef, 2003). For the Rokytka experiments, this procedure was applied for both dyes, BB and FLC, thus for two different groups of photographs. To detect and analyze FLC in the soil profile photographs similarly to the $\mathrm{BB}$ photographs, the dye detection routine in the original IDL code was adapted for optimal FLC identification.

\subsection{Headwater stream and spring sensing and sampling}

All sprinkling plots were located approx. $10 \mathrm{~m}$ away from the headwater stream in the lower concave part of the hillslope. 
Rainfall runoff data at the Rokytka catchment indicate that $10-15 \mathrm{~mm}$ of precipitation produce a noticeable response in the stream when the peat bog is in moist, near-saturated conditions (Vlček et al., 2016). Hence, the amount of sprinkling water $(40 \mathrm{~mm}$ per plot) simulated a rainfall that connects the hillslopes to the riparian zone and the headwater stream. Thus, the tracer FLC could potentially appear in the stream. During early summer conditions, similar to the conditions of the experiments with comparable antecedent soil moisture and groundwater levels, $40 \mathrm{~mm}$ of daily rainfall (on the entire catchment) rises the discharge from baseflow to peak flows on the order of $1.5 \mathrm{~mm} \mathrm{~h}^{-1}$. To detect whether and when the hillslopes connect to the stream, we installed two automated water samplers (ISCO 6700) in the vicinity of the sprinkling area in the stream and one at the catchment outflow to sample stream water for future analysis (Fig. 1). Each sampler detected one hillslope. A field fluorometer (Albilia GGUNFL30, detection limit $2 \times 10^{-11} \mathrm{~g} \mathrm{~mL}^{-1}$ ) was installed in the stream at the Rokytka headwater gauge in order to detect hydrologic connectivity, to capture the travel time of FLC from the sprinkling plots to the stream, and to possibly monitor the FLC break-through curve. The sampling interval was 15 min, allowing for continuous operation of the field fluorometer for 2 weeks. Moreover, water-level proportional water samplers WLPWS (Schneider et al., 2013) were installed at the same places as the ISCO samplers (two springs and at the gauge).

\section{Results}

\subsection{Mineral soil hillslope, Podzol (PZ2)}

Visible BB dye-stained patterns of lateral preferential flow in the soil profiles were observed up to a distance of $0.5 \mathrm{~m}$ outside the BB-sprinkling plot in the downslope direction $( \pm$ along the thalweg). Additional exploratory trenches were excavated 2 and $3 \mathrm{~m}$ downslope from the plot to detect further dye-stained patterns of lateral subsurface flow in the soil, but no traces of BB were found. Thus, the systematic excavation started $1.5 \mathrm{~m}$ downslope of the BB-sprinkling plot (Fig. 4). Figure 5a shows a selected lateral soil pit profile (IL1), which is mostly within the BB-sprinkling plot at the mineral soil hillslope. BB infiltrated rather homogeneously into the upper soil horizon $(\mathrm{O}+\mathrm{A})$ and percolated rather heterogeneously deeper into the soil. Thus, BB-stained patterns are placed irregularly at lower soil horizons, some of which reached down to the $\mathrm{B} / \mathrm{C}$ horizon without continuous connection to the topsoil in the excavation plain. The frontal soil profile (Fig. 5b) located outside the sprinkling plot confirms the prominence of BB-stained lateral-horizontal flow paths in the shallow subsurface, namely in the uppermost soil horizons $(\mathrm{O}+\mathrm{A}, \mathrm{A} / \mathrm{B})$. Some BB-stained patterns were observed at deeper soil horizons of the profile indicating preferential infiltration independent of specific soil horizon or depth. Stones and roots occur rarely and thus do not sig- nificantly modify lateral or vertical dye-stained flow structures. BB was transported vertically along patches in the soil matrix, typically at locations where the higher soil horizons $\mathrm{O}+\mathrm{A}$ and/or $\mathrm{A} / \mathrm{B}$ were stained. These vertical preferential flows were rather created by slight differences in texture and porosity of the soil matrix than by vertical macropore structures such as root networks or burrows. There were no visible vertical macropores. The root systems of the spruce stands are mostly limited to a depth of $0.2 \mathrm{~m}(\mathrm{O}+\mathrm{A}$ and $\mathrm{A} / \mathrm{B}$ horizons) and traces of edaphone are very limited. The local soil at profile AC0.5 (Fig. 5b) was not pre-sprinkled and thus likely less saturated when compared with the lateral profile located within the sprinkling plot (Fig. 5a). This may explain the more pronounced dye-stained vertical flow structures in the AC0.5 frontal profile compared to the pre-sprinkled IL1 lateral profile.

The dye FLC was not visible at the soil surface outside of the sprinkling plot. First exploratory trenches were excavated at a distance of $2 \mathrm{~m}$ downslope of the sprinkling plot; none of them showed any dye-stained patterns in the soil profiles. The systematic excavation started $1.5 \mathrm{~m}$ downslope from the sprinkling plot similar to the BB plot at hillslope PZ2 (Fig. 1). FLC dye-stained patterns are located without any visible link to the soil horizons, roots or stones (Fig. 6a and b). FLC dye was sparsely distributed in the topsoil horizons $(\mathrm{O}+\mathrm{A}, \mathrm{A} / \mathrm{B})$. Almost no dye-stained patterns were found in the lateral soil profiles, especially in the lower soil horizons, within the sprinkling plot area (e.g., Fig. 6a). The largest occurrence of FLC dye-stained soil patterns were found at frontal profile AC 0.5 in the Bh soil horizon - horizon enriched with humus substances (Fig. 6b).

The smallest stained spots $\left(<1 \mathrm{~cm}^{2}\right)$ were likely caused by UV light reflected from small grains of quartz from the weathered gneiss. The adopted version of the FLC dye classification algorithm could not distinguish these pixel-scale patches from truly FLC dye-stained features. However, this analytical bias has a negligible impact on the main findings concerning the FLC dye-staining in the mineral soil profiles (PZ2).

\subsection{Organic soil hillslope, peat bog (PB3)}

The visual survey of the soil surface in the vicinity of the BBsprinkling plot revealed near-surface flow in the northwestern (NW) direction towards the stream. BB was detected in a small, water-filled depression $10.5 \mathrm{~m}$ downslope from the sprinkling plot. A few excavations were performed from this point uphill towards the dye-sprinkling plot; systematic excavation and profile photographic documentation started $1.5 \mathrm{~m}$ downslope of the plot with a spacing of $0.25 \mathrm{~m}$ (Fig. 4a, yellow section). The BB-stained flow paths did not strictly follow the terrain gradient but went from the NW side of the sprinkling plot and followed mostly lateral preferential flow structures formed by decomposed trees or roots. This lateral preferential flow path was later identified as the main 

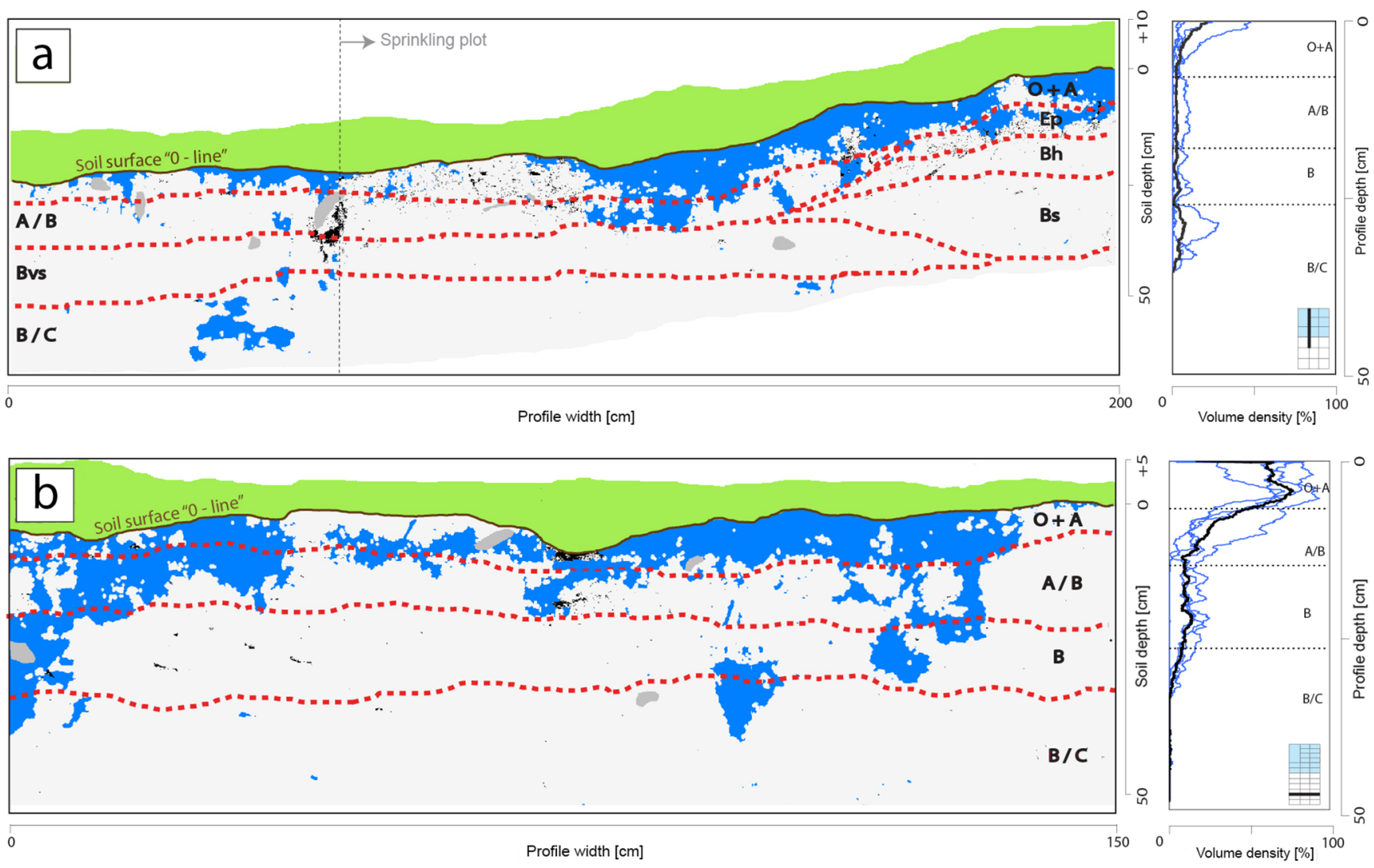

Figure 5. (a) Lateral profile IL1 and (b) frontal profile AC0.5 at the Brilliant Blue (BB)-sprinkling plot PZ2 at the mineral soil hillslope (Podzol). The position of the profile is indicated in bottom right corner. Blue: BB dye; gray: stones, roots; green: vegetation; black: unclassified shadows, roots; red-dotted line: soil horizon divide. The charts on the right represent the distribution of the volume density of BB in different soil depths. Ep is elusive podzol horizon; Bh is podzol horizon enriched with humus substances; Bs is podzol horizon with significant sesquioxide content.

direction of the subsurface flow. Relatively smaller and less stained flow paths were observed downslope from the sprinkling plot (Fig. 4a, orange section), with BB disappearing $2 \mathrm{~m}$ from the sprinkling plot. The BB excavation started the day after the sprinkling, yet dye stored in large macropore pockets started flowing down the trench walls when these soil structures were truncated. BB followed lateral soil pipes that were formed by decomposed roots or fallen trees. Healthy trees and undecomposed timber did not create such effective lateral preferential flow paths; therefore, they had no significant impact on dye-stained patterns (Fig. 7). BB created clearly detectable dye-stained patterns on the dark peat particles as well, so the major flow paths of BB could be detected even several days after the dye application. The excavation of BB-stained soil patterns at the organic soil hillslope PB3 proceeded from two directions (NW and SW, Fig. 4a) following the stained flow paths in the soil. Near the sprinkling plot, most of the dye was detected at the surface and in nearsurface soil horizons, which correlates with acrotelm (Fig. 7). About $2.0 \mathrm{~m}$ downslope from the BB-sprinkling plot at hillslope PB3 (Fig. 1), the dye-stained patterns diminished in the acrotelm and were observed mainly in and around macropores in the catotelm. The excavation caused problems at location FD0.25/profile D $0-1$ as dye-filled macroporous pockets in the soil drained BB when disturbed during excavation and thus secondarily stained these soil profiles. Such secondary patterns were cleaned to minimize falsely detected $\mathrm{BB}$ along the excavation front.

The excavation of the FLC-sprinkling plot at PB3 at the organic soil hillslope (peat bog) started $3 \mathrm{~h}$ after sprinkling after dark. Repeated visual surveys of the terrain surface and of the excavated soil trenches downslope of the sprinkling plot using the UV lamp $(410 \mathrm{~nm})$ and UV torches $(385 \mathrm{~nm})$ did not detect any traces of FLC at the surface or in the soil pits. Even in the soil horizons within the sprinkling plot, no FLC dyestained flow patterns were identified. Only parts of the vegetation at the surface of the sprinkling plot itself were visibly stained with FLC. FLC was later detected in a small waterfilled depression about $2.5 \mathrm{~m}$ downslope from the sprinkling plot PB3.

Traces of FLC were not detected in the headwater stream, neither in any water samples taken by automated water sam- 

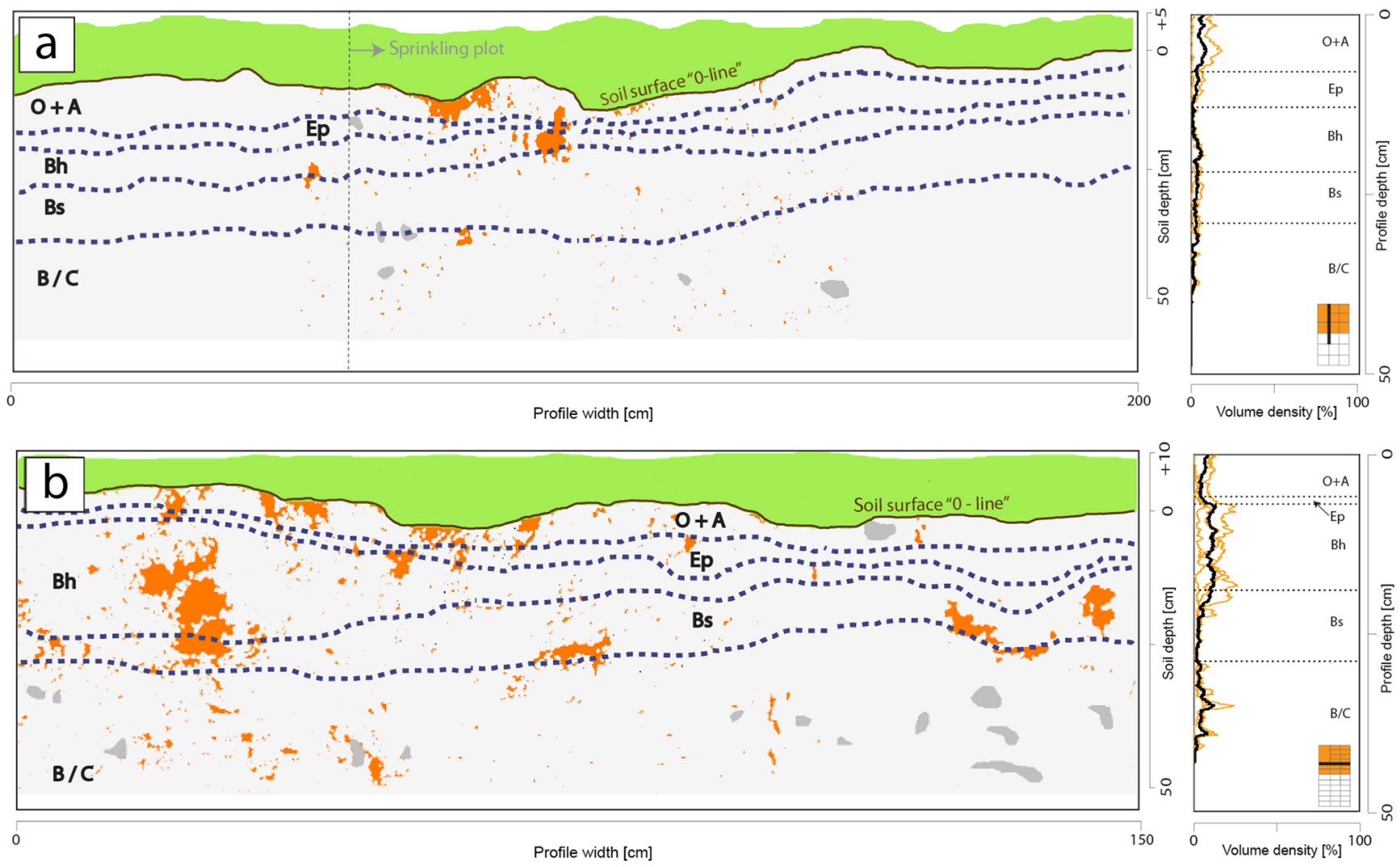

Figure 6. (a) Lateral soil profile IL1 and (b) frontal soil profile AC0.5 at the Fluorescein sodium (FLC)-sprinkling plot PZ2 at the mineral soil hillslope (Podzol). The position of the profile is indicated in bottom right corner. Orange: FLC dye; gray: stones, roots; green: vegetation; black: unclassified shadows; dark-blue dotted lines: soil horizon divide. The charts on the right represent the dye volume in different depths below the soil surface.

plers (ISCO 6700) or water-level proportional water samplers WLPWS, nor with the field fluorometer during the 14day monitoring period following the dye application.

\section{Discussion}

Hillslope hydrology is concerned with the partition of precipitation as it passes through the vegetation and soil between overland flow and subsurface flow (Kirkby, 1988). Runoff formation at hillslopes (zero-order basin response) and in riparian zones (first- and second-order stream response) are the main controls defining the hydrologic response of mountainous headwaters in humid climates. Vertical processes and lateral connectivities are strongly dependent on soil properties, thus soil types are a major regulator of the interplay of these processes. Soil types can be classified in hydrologically meaningful terms, e.g., according to HOST (Boorman et al., 1995).

Hillslope processes define how small catchments respond to rainfall (Anderson and Burt, 1990). Specifically, hillslope processes control how long water is stored in soil or bedrock, which determines how quickly small catchments respond to rainfall (Uhlenbrook et al., 2008). Our experiments in the Šumava Mts. showed that the peat bog hillslope connected much more quickly to the stream and contributed considerably more to the runoff response of the headwater than the Podzol hillslope. The larger Rokytka catchment $\left(3.8 \mathrm{~km}^{2}\right.$, third-order stream) showed similar hydrologic behavior (Fig. 2) - low baseflow and flashy storm hydrographs - to the smaller Rokytka headwater $\left(0.6 \mathrm{~km}^{2}\right.$, second-order stream). This is noteworthy since the proportion of the peat bog ranges from $60 \%$ at the second-order stream headwater to less than $30 \%$ at the third-order stream catchment; the remaining areas are covered by Podzol. This illustrates that the hydrologic response of the catchment is dominated by the runoff formation at the peat bog, whereas we speculate that a deep groundwater system is fed by percolation in the Podzol that is rather disconnected from the second- and third-order streams.

\subsection{Mineral soil hillslope, Podzol (PZ2)}

Based on the properties of Podzol, surface flow (SOF or HOF) at the mineral soil hillslope PZ was not expected. This hypothesis was supported by the results of the BB staining 

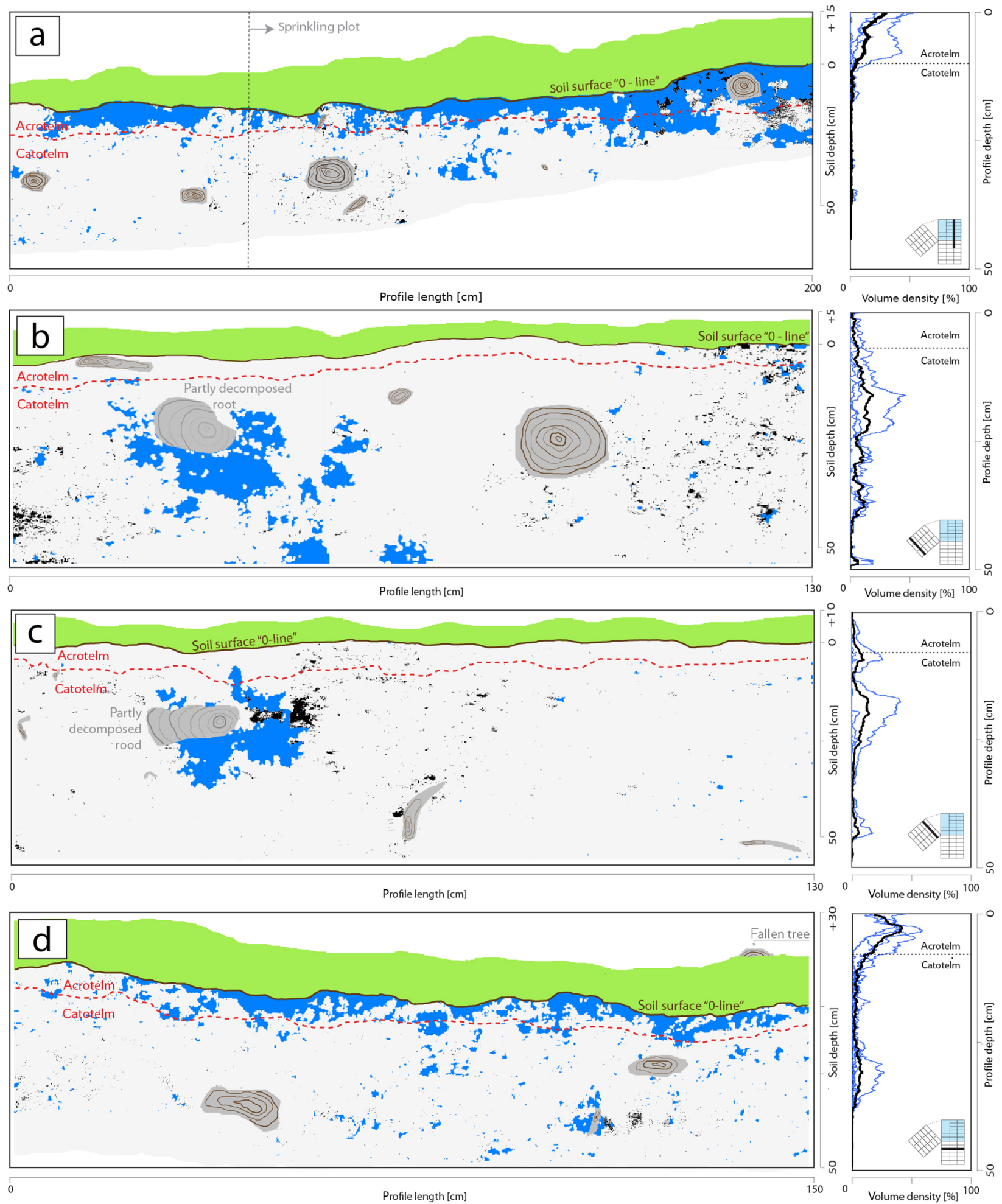

Figure 7. (a) Lateral soil profile IL0.5, and (b) frontal soil profile FD0.25 at the Brilliant Blue (BB)-sprinkling plot PB3 at the organic soil hillslope (peat bog). The position of the profile is indicated in bottom right corner. Blue: BB dye; gray: roots; green: vegetation; black: unclassified shadows; red-dotted line: soil horizon divide. The charts on the right represent the vertical distribution of the volume density of the BB. The reduced width of the soil profiles shown in Fig. $7 \mathrm{~b}$ and $\mathrm{c}$ are due to the presence of a tree stump on the right side of these profiles. (c) Profile FD1.25 and (d) frontal profile AC1 at the BB-sprinkling plot PB3 at the organic soil hillslope (peat bog). The position of the profile is indicated in bottom right corner. Blue: BB dye; gray: roots; green: vegetation; black: unclassified shadows; red-dotted line: soil horizon divide. The charts on the right represent the vertical distribution of the volume density of the BB. The reduced width of the soil profiles shown in Fig. $7 \mathrm{~b}$ and $\mathrm{c}$ is due to the presence of a tree stump on the right side of these profiles. 


$$
\text { (a) slope PZ }
$$

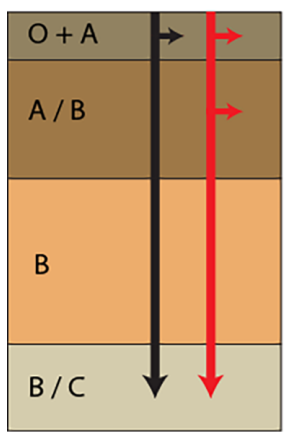

(b) slope PB

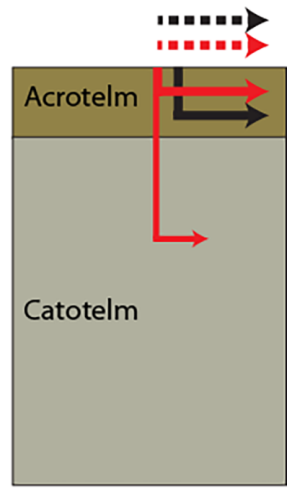

Figure 8. Conceptual models of runoff formation and (subsurface) stormflow for the organic soil hillslope (peat bog PB3) and the mineral soil hillslope PZ (Podzol) derived by parallel plot sprinkling experiments with the conservative dye Fluorescein sodium (FLC) and the sportive dye Brilliant Blue (BB) at the Rokytka headwater. Detected subsurface-flow components at the PZ hillslope (a) biomat flow, shallow lateral subsurface flow and mostly deep percolation (vertical), and at the organic soil hillslope PB (peat bog) (b) biomat flow at short distances and mostly lateral pipe flow following decayed tree-root systems with long lateral subsurface-flow distances. The dashed arrows represent surface flow (saturation overland flow, SOF), which could not be detected during the experiments but has been observed on-site during natural storm events. Black arrows: hypothesized runoff formation processes according to the Hydrology of Soil Types classification (HOST; Boorman et al., 1995); Red arrows: results of the Šumava experiments.

patterns in the soil profiles at PZ2. However, the dye did not identify a hydrologic active soil horizon as clearly as with the Gleysol hillslope study (Schneider et al., 2014). The most abundantly stained soil structures (volume density of up to $85 \%$, Fig. 5b) were found within the uppermost soil horizon $\mathrm{O}+\mathrm{A}$, up to a depth of $0.1 \mathrm{~m}$ below the surface. The shape of the BB depth distribution was similar at the plot; however, the volume density of max. $50 \%$ is significantly lower (Fig. 5a). Based on the soil properties at the mineral soil hillslope PZ2, such as porosity and hydraulic conductivity, infiltration was expected to be rather stable and homogeneous. However, BB infiltrated heterogeneously. Parts of the topsoil created conditions for the occurrence of fingering (DiCarlo et al., 2013) or similar types of matrix preferential flow (Weiler and Flühler, 2004; Anderson et al., 2009; Wienhöfer et al., 2009). Similar to previous work, we attribute the heterogeneous infiltration to the corrugated transition between the dark organic topsoil horizons $(\mathrm{O}, \mathrm{A})$ and the lower mineral horizons $(\mathrm{A} / \mathrm{B}, \mathrm{B})$. However, Weiler and Flühler (2004), Anderson et al. (2009) and Wienhöfer et al. (2009) conducted their studies at steeper slopes and on different soil types compared to the Šumava experiments. A sharp interface between an upper organic and a lower "organo-mineral" layer like in the Šumava sprinkling experiments can initiate significant biomat flow (Gerke et al.,
2015) that can be attributed to water repellency (Doerr et al., 2000). Water repellency of the soil surface was observed in the organic topsoils at the Rokytka headwater during dry periods. However, due to rainfall events prior to our experiments, the antecedent soils moisture conditions $(0.45-0.5)$ likely did not support water repellency in the topsoil (Fig. 2). At PZ2, BB was clearly visible at deeper soil horizons, where it created seemingly detached stained patterns. These stained patterns represent vertical preferential flow paths (Nobles et al., 2010; Gerke et al., 2015; Uchida et al., 2005), but the excavation spacing $(0.25-0.5 \mathrm{~m})$ was probably too coarse to detect connected stained flow paths in full detail. Horizontallateral preferential flow paths dominated at the topsoil layers $(\mathrm{O}+\mathrm{A})$, whereas vertical flow directions (percolation) dominated at the lower soil horizons. These differences in the direction of stained pathways are consistent with the results of Schneider et al. (2014) or Gerke et al. (2015).

FLC stained significantly fewer soil structures or pathways compared to $\mathrm{BB}$ at both hillslopes. FLC was almost absent with few exceptions in the near-surface organic topsoil layers. This could be because of the relatively small amount of dyed water $(20 \mathrm{~mm}$ dyed sprinkling water and $20 \mathrm{~mm}$ undyed pre-sprinkling water). Previous FLC soil staining experiments used simulated rainfalls of 50-100 mm (Gerke et al., 2015). The size of the irrigation plots $(1.5 \mathrm{~m} \times 1.5 \mathrm{~m})$ does not appear to be a factor, as previous work used irrigation plots that were $1 \mathrm{~m} \times 1 \mathrm{~m}$, and successfully detected FLC (Gerke et al., 2015). The FLC dye solution could have bypassed the topsoil horizons via macropores and soil pipes without visibly staining these preferential flow structures due to various causes, e.g., local hydrophobicity (Doerr et al., 2000) or strong acidity. On the other hand, FLC-stained patterns in the lower soil horizons at the Podzol plots are similar to the BB-stained patterns. This indicates, that the organic topsoils at the Šumava test sites may suppress the fluorescence of FLC in addition to the well-known $\mathrm{pH}$ induced fluorescence elimination. At the Podzol hillslope PZ2 the FLCstained soil patterns suggest rather a subsurface lateral pipeflow network as described in Uchida et al. (2005) than biomat flow as identified by Gerke et al. (2015).

\subsection{Organic soil hillslope, peat bog (PB3)}

BB at the peat bog hillslope PB3 did not detect surface flow SOF or significant vertical deep percolation. BB patterns in the soil profiles supported the hypothesis of nearsurface biomat flow, which can be attributed to lateral preferential flow in the acrotelm. Differences in porosity and hydraulic conductivity between acrotelm and catotelm create similar stained patterns when compared to the Gleysol hillslope studied in the experiment of Schneider et al. (2014). The infiltration process at the hillslope PB3 matches fairly well the definition of lateral subsurface stormflow (Wienhöfer et al., 2009). Lateral preferential flow was detected with BB at PB3; however, it was limited mostly to few, but well- 
connected pipe networks with high drainage capacity. These soil pipe networks are created by decomposed dead trees or dead roots in the Acro- and catotelm. Such lateral soil pipe networks are an important runoff formation process at peaty catchments (Jones, 1997; Holden and Burt, 2002). Holden and Burt (2003) identified the dominant lateral stormflow as shallow subsurface flow (SSF) down to the depth of $0.1 \mathrm{~m}$. However, BB at the organic soil hillslope PB3 showed that lateral soil pipes were connected both in Acro- and catotelm (depth $0.1-0.4 \mathrm{~m}$ ) to jointly form the major preferential flow paths through the peat bog. Hence, during the BB excavation soil pipes were only observed in the catotelm. BB dyestained flow paths in the soil appeared prominently further downslope (outside of the dye-sprinkling plot) and connected mostly laterally via soil pipes rather than vertically penetrating the acrotelm. However, most soil profiles - both frontal and lateral - document that the BB dye-stained flow paths are rather limited to macropore structures and rarely to matrix flow. Deep percolation at the organic soil hillslope PB3 was not detected. The assumption, that BB may be difficult to optically detected in such dark soils as peat bog, was not confirmed. It could be shown that BB can be successfully applied in peat bogs to stain vertical flow structures in soil profiles and has the potential to trace rather long-distance lateral preferential flow paths (distances $>10 \mathrm{~m}$ ) in waterlogged areas with shallow groundwater $(\sim 0.5 \mathrm{~m}$ below surface).

The critical role of $\mathrm{pH}$ affecting Fluorescein's fluorescence and thus its on-site optical detection is well known (Gerke et al., 2013; Käss, 1998). Therefore, the FLC solution was buffered with $\mathrm{NaOH}$ to compensate for the strong acidity of the organic soil, similar to the approach successfully applied in FLC staining experiments in organic topsoils in Japan (Gerke et al., 2015). The rarely detected FLC at the peat bog hillslope does not necessarily indicate that no dye infiltrated into the upper organic layer as the dye's fluorescence could not be optically detected in situ. The FLC solution could have bypassed the organic topsoil horizons via macropores and soil pipes at the peat bog plot PB3 as well as at the Podzol plot PZ2. The very low soil $\mathrm{pH}$ in the peat bog might be the reason why FLC fluorescence was not observed. Although we attempted to increase the soil water $\mathrm{pH}$ by pre-sprinkling the plots with $\mathrm{NaOH}$-enriched water, and similarly buffered the FLC solution, these countermeasures at the sprinkling plots were probably not enough to significantly change the $\mathrm{pH}$ conditions in the soil at both hillslopes, but especially at PB3. FLC was mostly visible on organic surfaces such as plants (moss, grass) on the surface but not in the peat itself. This might be attributed to the tendency of FLC to attach to organic matter, which significantly counteracts its conservative behavior in mineral soils, especially in thick organic soils such as peat bogs. Furthermore, the "very strong acidity" in the peat bog soil, the phreatic zone and the capillary fringe together may have diluted any buffering effect of the $\mathrm{NaOH}$-enriched sprinkling water. However, FLC dye was visible the next day during daylight in a small, water-filled depression approximately $3.0 \mathrm{~m}$ downslope from the FLCsprinkling plot. This indicates that the dye had been transferred via preferential flow in lateral soil pipes in the vadose zone and had not been completely (ab)sorbed by organic soil particles.

\subsection{Plots-stream hydrologic connectivity with Fluorescein}

Limitation and possible causes of failure of FLC staining and tracing experiments have been well described for organic and mineral soils by Gerke et al. (2008) and for groundwater and surface-water applications by Käss (1998). The most common problems were addressed for the Šumava experiments by

- pre-sprinkling of the plot with $\mathrm{NaOH}$ buffered water (pH 12);

- addition of $\mathrm{NaOH}$ to the FLC solution to create a secondary $\mathrm{pH}$ buffer;

- avoiding bright sunlight as FLC is light sensitive and decays quickly, by performing the FLC sprinkling and excavation work at night with controlled short-time exposure to UV and visual spectra light.

Despite our advanced and dense FLC monitoring network in all tributaries and springs draining the hillslopes field fluorometer, automated water samplers and water-level proportional water samplers (Schneider et al., 2013), FLC was not detected in the stream or at the springs. As a result, we could neither measure a tracer breakthrough nor could we delineate a transit time or prove hydrologic connectivity from the sprinkling plots to the drainage system. The following explanations may explain why FLC did not reach the drainage system:

- small sprinkling water volume and limited area of the sprinkling plots $(1.5 \mathrm{~m} \times 1.5 \mathrm{~m})$ compared to the distance from the plots to the stream or springs $(10 \mathrm{~m})$;

- masking of the FLC fluorescence by very low background $\mathrm{pH}$ values (Käss, 1998);

- fluorescence reduction and masking of FLC by organic substances (Käss, 1998);

- sorption of FLC to vegetation and topsoil organic matter.

As the sprinkling solution mixed with soil and shallow groundwater, its $\mathrm{pH}$ probably dropped back to low background $\mathrm{pH}$ values. Another reason for null detection of FLC might be the relatively small amount of water sprinkled at the plot compared to the soil and groundwater volume. The influence of the capillary fringe and the soil matrix to dilute the $\mathrm{pH}$-enriched sprinkling water might be significant, but the presented data cannot confirm or disprove this possibility. 


\subsection{Dominant runoff formation}

In extension to our hypothesis, which was based on the conceptual runoff formation model, HOST model A, (Boorman et al., 1995; Figs. 1 and 8) we found that additional lateral subsurface flow in deeper soil horizons occurred at the mineral hillslope PZ2 (Podzol). As predicted, a near-surface runoff formation process occurred in parallel to deep percolation (Fig. 8). Biomat flow, a shallow subsurface flow in the topmost soil horizon O+A (Sidle et al., 2007; Gerke et al., 2015) is thus a relevant runoff formation process at the mineral hillslope PZ2 (Podzol). The absence of a shallow groundwater body and percolation-restricting soil layers buffers the lateral stormflow at the hillslope PZ2, as a large portion of precipitation infiltrates into the soil and percolates into the underlying bedrock. These findings are supported by the lack of temporary or fully saturated zones, perched aquifers or a groundwater body rising into the soil (transmissivity feedback), which may connect the hillslope to the stream and thus effectively drained the Podzol (Fig. 8). According to the runoff formation decision scheme by Scherrer and Nae (2003), the dominant runoff formation process at the Podzol hillslope can be classified as a combination of delayed HOF and delayed subsurface stormflow (SSF2). The sprinkling experiments with the dyes (BB and FLC) showed the existence of vertical and lateral preferential pathways in the topsoil and indicated that delayed subsurface-flow SSF occurs also.

At the organic soil hillslope PB3, the hypothesized HOST model K (Boorman et al., 1995) was supported by our results. Biomat flow and lateral preferential flow in soil pipe networks formed by decaying fallen trees and roots in the acrotelm and - in addition to our prediction also in the catotelm - are the primary runoff formation processes at the peat bog hillslope (Fig. 8). Our hypothesis of HOF was confirmed for the peat bog hillslope PB3 by the results of the sprinkling experiments with Brilliant Blue. It is necessary to notice that the results should be interpreted with respect to the relatively small size of the sprinkling plots $(1.5 \mathrm{~m} \times 1.5 \mathrm{~m})$ compared to the entire hillslopes, which were not sprinkled.

\section{Conclusions}

In this study runoff formation during stormflow was investigated at two opposite hillslopes with different soil types (Histosol/Peat, Podzol) in a second-order mountain headwater catchment in the Czech Republic. Two dye tracers with different attributes - the sorptive dye Brilliant Blue (BB), and the conservative dye Fluorescein sodium (FLC) - were applied to stain preferential flow paths in the soil and at its surface.

At the peat bog hillslope, BB staining identified a quickly activated and effective shallow lateral subsurface drainage system in the acrotelm. Preferential flow structures connected the hillslope with the not-sprinkled riparian zone via lateral pipe flow along decayed roots and fallen trees in the acrotelm, and the upper catotelm. Healthy roots did not create similar drainage-effective, well-connected lateral preferential flow structures as decomposed roots or dead trees at the peat bog site. In contrast, subsurface flow at the Podzol hillslope was created only near surface in the organic topsoil (biomat flow). The lateral subsurface transport in the unsaturated zone at the organic soil hillslope (peat bog) was about an order of magnitude higher (10 m lateral flow) than at the mineral soil hillslope (Podzol, $1 \mathrm{~m}$ lateral flow). At the mineral soil hillslope (Podzol) both dye tracers worked well in the subsoil and delivered similar results. Percolation in the soil and deep percolation into the bedrock dominated, as expected; lateral preferential drainage was rather limited. Compared to the organic soil hillslope (peat bog), the lateral subsurface-flow distance is reduced by an order of magnitude $(1 \mathrm{~m}$ vs $10 \mathrm{~m})$. The findings at the Podzol hillslope with prevailing vertical flow agree with the facts that groundwater influenced soil horizons could not be detected in soil profiles.

We were more easily able to detect hydrologic connectivity from the hillslope to the riparian zone with $\mathrm{BB}$ than with FLC at the peat bog hillslope. This is surprising, as BB is considered to be more sorptive (less conservative) than FLC. Moreover, the dark-blue BB is often difficult to optically detect in dark organic soils like Peat. We attribute this finding to the fact that BB is less affected than FLC by the very strongly acidic soil and groundwater $(\mathrm{pH}<5)$ found in peaty environments such as the Šumava headwaters.

Data availability. The data used in this study can be obtained upon request to the Department of Physical Geography and Geoecology, Charles University, Prague, Czech Republic.

\section{The Supplement related to this article is available online at https://doi.org/10.5194/hess-21-3025-2017- supplement.}

Author contributions. LV, KF, and PS participated in the experiment and contributed to the manuscript.

Competing interests. The authors declare that they have no conflict of interest.

Acknowledgements. The authors would like to thank Jan Seibert from the University of Zürich for providing equipment and tools, Bohumír Janský from Charles University, Prague, for help and financial support, and Markus Weiler from the University of Freiburg for providing his IDL code for the Brilliant Blue image analysis. We are indebted to Václav Královec, Miroslav Šobr, 
Michal Jeníček, Zdeněk Kliment, Luděk Šefrna, Jan Kocum, Julius Česák, Jitka Vlčková and Jiří Vlček for support and assisting with fieldwork, to Sarah Kliegman, Keck Science Department of Claremont McKenna, Pitzer, and Scripps Colleges, for helpful comments, suggestions and proofreading, and to the National Park Šumava for permission to conduct our research on its land. This work was supported by project GAČR 13-32133S "Headwaters retention potential with respect to hydrological extremes", and by project COST ES1306, LD 15130 "Impact of landscape disturbance on stream and basin connectivity".

Edited by: Markus Weiler

Reviewed by: Bernhard Kohl and one anonymous referee

\section{References}

Anderson, A. E., Weiler, M., and Alila, Y., and Hudson, R. O.: Dye staining and excavation of a lateral preferential flow network, Hydrol. Earth Syst. Sci., 13, 935-944, https://doi.org/10.5194/hess-13-935-2009, 2009.

Anderson, M. G. and Burt, T. P.: Process Studies in Hillslope Hydrology, Wiley, Winchester, UK, 1990.

Bachmair, S. and Weiler, M.: Hillslope characteristics as controls of subsurface flow variability, Hydrol. Earth Syst. Sci., 16, 36993715, https://doi.org/10.5194/hess-16-3699-2012, 2012.

Bachmair, S., Weiler, M., and Nützmann, G.: Controls of land use and soil structure on water movement: Lessons for pollutant transfer through the unsaturated zone, J. Hydrol., 369, 241-252, ISSN 0022-1694, 2009.

Boorman, D.B., Hollis, J.M., and Lilly, A.: Hydrology of soil types: a hydrologically-based classification of the soils of the United Kingdom, Institute of Hydrology report no. 126, 1995.

Brázdil, R., Trnka, M., Mikšovský, J., Řezníčková, L., and Dobrovolný, P.: Spring-summer droughts in the Czech Land in 1805-2012 and their forcings, Int. J. Climatol., 35, 1405-1421, https://doi.org/10.1002/joc.4065, 2015.

Dicarlo, D. A.: Stability of gravity-driven multiphase flow in porous media: 40 Years of advancements, Water Resour. Res., 49, 45314544, https://doi.org/10.1002/wrcr.20359, 2013.

Doerr, S. H., Shakesby, R. A., and Walsh, R. P. D.: Soil water repellency: Its causes, characteristics and hydrogeomorphological significance, Earth Sci. Rev., 51, 33-65, https://doi.org/10.1016/S0012-8252(00)00011-8, 2000.

Evans, M. G., Burt, T. P., Holden, J., and Adamson, J. K.: Runoff generation and water table fluctuations in blanket peat: evidence from UK data spanning the dry summer of 1995, J. Hydrol., 221, 141-160, https://doi.org/10.1016/S0022-1694(99)00085-2, 1999.

Faist, H.: Die jährlichen Hochwasserabflüsse der Elbe bei Magdeburg im Zeitraum von 1870 bis 1960, Dokumentation der Wasserwirtschaftsdirektion Mittlere Elbe Sude-Elbe, 1967.

Ferda, J., Hladný, J., Bubeníčková, L., and Pešek, L., 1971.Odtokový režim a chemismus vod v povodí Horní Otavy se zaměřením na výskyt rašeliništ, Sborník prací HMÚ, 17, HMÚ, Praha, 22-126, 1971.

Flury, M. and Flühler, H.: Tracer Characteristics of Brilliant Blue FCF, Soil Sci. Soc. Am. J., 59, 22-27, https://doi.org/10.2136/sssaj1995.03615995005900010003x, 1995.

Gerke, K. M., Sidle, R. C., and Tokuda, Y.: Sorption of Uranine on forest soils, Hydrol. Res. Lett., 2, 32-35, https://doi.org/10.3178/hrl.2.32, 2008.

Gerke, K. M., Sidle, R. C., and Mallants, D.: Criteria for selecting fluorescent dye tracers for soil hydrological applications using Uranine as an example, J. Hydrol. Hydromech., 61, 313-325, https://doi.org/10.2478/johh-2013-0040, 2013.

Gerke, K. M., Sidle, R. C., and Mallants, D.: Preferential flow mechanisms identified from staining experiments in forested hillslopes, Hydrol. Process., 29, 4562-4578, https://doi.org/10.1002/hyp.10468, 2015.

Hladný, J.: Jaké následky přineslo sucho v roce 2003? In Němec, J., Kopp, J. (Eds.): Vodstvo a podnebí v České republice, MZE ČR, Consult Praha, 81, 2009.

Hladný, J., Kašpárek, L., Krátká, M., Kněžek, M., and Martínková, M.: Katastrofální povodeň v České republice v srpnu 2002, MŽP ČR, Praha, 68, 2005.

Holden, J.: Piping and woody plants in peatlands: Cause or effect?, Water Resour. Res., 41, 1-10, https://doi.org/10.1029/2004WR003909, 2005.

Holden, J. and Burt, T. P.: Piping and pipeflow in a deep peat catchment, Catena, 48, 163-199, https://doi.org/10.1016/S03418162(01)00189-8, 2002.

Holden, J. and Burt, T. P.: Hydrological studies on blanket peat: The significance of the acrotelm-catotelm model, J. Ecol., 91, 86102, https://doi.org/10.1046/j.1365-2745.2003.00748.x, 2003.

Holden, J., Burt, T. P., and Cox, N. J.: Macroporosity and infiltration in blanket peat: The implicaions of tension disc infiltrometer measurements, Hydrol. Process., 15, 289-303, https://doi.org/10.1002/hyp.93, 2001.

Hümann, M., Schüler, G., Müller, C., Schneider, R., Johst, M., and Caspari T.: Identification of runoff processes - The impact of different forest types and soil properties on runoff formation and floods, J. Hydrol., 409, 3-4, 637-649, ISSN 0022-1694, https://doi.org/10.1016/j.jhydrol.2011.08.067, 2011.

IUSS Working Group WRB: World reference base for soil resources 2006, 2nd edition. World Soil Resources Reports No. 103. FAO, Rome, ISBN 92-5-105511-4, 2006.

Janský, B. and Kocum, J.: Peat Bogs influence on runoff process: Case study of the vydra and křemelná river basins in the šumava mountains, Southwestern Czechia, Geografie, 113, 383399, 2008.

Jones, J. A. A.: Pipeflow contribution areas and runoff response, Hydrol. Process., 11, 35-41, 1997.

Käss, W.: Tracing technique in geohydrology: Rotterdam, A. A. Balkema, 581 pp., 1998.

Kirkby, M.: Hillslope runoff processes and models, J. Hydrol., 100, 315-339, 1988.

Kocum, J., Oulehle, F., Janský, B., Bůzek, F., Hruška, J., and Vlček, L.: Geochemical evidence for Peat Bog contribution to streamflow generation process: case study of Vltava River headwaters, Czech Republic, Hydrol. Sci. J., 61, 2579-2589, https://doi.org/10.1080/02626667.2016.1140173, 2016.

Langhammer, J., Su, Y., and Bernsteinová, J.: Runoff response to climate warming and forest disturbance in a mid-mountain basin, Water (Switzerland), 7, 3320-3342, https://doi.org/10.3390/w7073320, 2015. 
Nobles, M. M., Wilding, L. P., and Lin, H. S.: Flow pathways of bromide and Brilliant Blue FCF tracers in caliche soils, J. Hydrol., 393, 114-122, https://doi.org/10.1016/j.jhydrol.2010.03.014, 2010.

Rizzuti, A. M., Cohen, A. D., and Stack, E. M.: Using hydraulic conductivity and micropetrography to assess water flow through peat-containing wetlands, Int. J. Coal Geol., 60, 1-16, https://doi.org/10.1016/j.coal.2004.03.003, 2004.

Schneider, P.: Hydrologische Vernetzung und ihre Bedeutung für diffuse Nährstoffeinträge im Hotzenwald/Südschwarzwald, Physiogeographica - Basler Beiträge zur Physiogeographie, 177, available at: edoc.unibas.ch/823/1/DissB_8420.pdf (last access: 10 December 2016), 2007.

Schneider, P., Lange A., and Doppler, T.: Development and evaluation of a water level proportional water sampler, American Geophysical Union, Fall Meeting 2013, abstract \#H43H-1579, 2013.

Schneider, P., Pool, S., Strouhal, L., and Seibert, J.: True colors experimental identification of hydrological processes at a hillslope prone to slide, Hydrol. Earth Syst. Sci., 18, 875-892, https://doi.org/10.5194/hess-18-875-2014, 2014.

Scherrer, S. and Naef, F.: A decision scheme to indicate dominant hydrological flow processes on temperate grassland, Hydrol. Process., 17, 391-401, https://doi.org/10.1002/hyp.1131, 2003.

Seibert, J., Grabs, T., Köhler, S., Laudon, H., Winterdahl, M., and Bishop, K.: Linking soil- and stream-water chemistry based on a riparian flow-concentration integration model, Hydrol. Earth Syst. Sci., 13, 2287-2297, https://doi.org/10.5194/hess-13-22872009, 2009.

Sidle, R. C., Hirano, T., Gomi, T., and Terajima, T.: Hortonian overland flow from Japanese forest plantations - an aberration, the real thing, or something in between?, Hydrol. Process., 21, 32373247, https://doi.org/10.1002/hyp.6876, 2007.

Uchida, T., Tromp-Van Meerveld, I., and McDonnell, J. J.: The role of lateral pipe flow in hillslope runoff response: An intercomparison of non-linear hillslope response, J. Hydrol., 311, 117-133, https://doi.org/10.1016/j.jhydrol.2005.01.012, 2005.
Uhlenbrook, S., Didszun, J., and Wenninger, J.: Source areas and mixing of runoff components at the hillslope scale - a multi-technical approach, Hydrological Sciences Journal - Journal des Sciences Hydrologiques, 53, 741-753, https://doi.org/10.1623/hysj.53.4.741, 2008.

Vlček, L., Kocum, J., Janský, B., Šefrna, L., and Kučerová, A.: Retenční potenciál a hydrologická bilance horského vrchoviště: případová studie Rokytecké slatě, povodí horní Otavy, JZ Česko, Geografie, 4, 2012.

Vlček, L., Kocum, J., Janský, B., Šefrna, L., and Blažková, Š.: Influence of peat soils on runoff process: case study of Vydra River headwaters, Czechia, Geografie, 121, 235-253, 2016.

Von Freyberg, J., Radny, D., Gall, H. E., and Schirmer, M.: Implications of hydrologic connectivity between hillslopes and riparian zones on streamflow composition, J. Contam. Hydrol., 169, 6274, https://doi.org/10.1016/j.jconhyd.2014.07.005, 2014.

Weiler, M.: Field-Based Observation of Hydrological Processes, in: Treatise on Water Science Academic Press, 339-350, 2011.

Weiler, M. and Flühler, H.: Inferring flow types from dye patterns in macroporous soils, Geoderma, 120, 137-153, https://doi.org/10.1016/j.geoderma.2003.08.014, 2004.

Weiler, M. and McDonnell, J. J., Tromp-van Meerveld, I., and Uchida, T.: Subsurface stormflow, in: Encyclopedia of Hydrological Sciences, edited by: Anderson, M. G. and McDonnell, J. J., John Wiley \& Sons, New York, 1719-1732, 2006.

Weiler, M. and Naef, F.: An experimetnal sudy of the role of macropores in infiltration in grassland soils, Hydrol. Process., 17, 477493, 2003.

Wienhöfer, J., Germer, K., Lindenmaier, F., Färber, A., and Zehe, E.: Applied tracers for the observation of subsurface stormflow at the hillslope scale, Hydrol. Earth Syst. Sci., 13, 1145-1161, https://doi.org/10.5194/hess-13-1145-2009, 2009. 